\title{
Molecular detection of Salmonella serovars in Retailed Raw Meat samples using 16SrRNA, sitC and fliC Virulence Genes in Lagos, Nigeria.
}

\author{
Anejo-Okopi JA ${ }^{1}$, Adamu $\mathrm{ME}^{2}$, Okwori $\mathrm{AEJ}^{3}$, Audu $\mathrm{O}^{4}$, Odeigah $\mathrm{PGC}^{5}$ \\ ${ }^{1}$ Microbiology department, University of Jos, Nigeria, \\ ${ }^{2}$ Jos University Teaching Hospital, AIDS Prevention Initiative Nigeria, Jos, Nigeria \\ ${ }^{3}$ Cell Biology and Genetics department, University of Lagos, Nigeria \\ ${ }^{4}$ Microbiology department, Federal College of Veterinary and Medical Laboratory Technology, Vom, Nigeria, \\ ${ }^{5}$ Department of Epidemiology and Community Health, College of Health Sciences, Benue State University, \\ Makurdi, Nigeria
}

\begin{abstract}
:
Introduction: The presence of virulence genes such assit $C$ and fli $C$ are known among Salmonella serovars of clinical interest. The common sources of Salmonella include dairy products, beef, poultry, eggs and vegetables. This study was aimed at identifying salmonella using $16 S$ ribosomal RNA gene (16SrRNA), andsitCandfliCvirulence genes in raw meat samples commonly sold in open market place genotypically with PCR methods.

Methods: The study observed the presence of Salmonella isolated from 124 raw meat samples using conventional phenotypic methods and analysing for presence of sitCandfliCvirulence genes. For molecular analysis, the 16S rRNAs of strains of Salmonella were used to confirm the result of the conventional method. DNA extraction and quantification was carried out followed by Polymerase Chain Reaction. The PCR products were subjected to agarose gel electrophoresis.

Result: A total of 124 isolates were collected from animal sources. Of the 124 samples, 30 Salmonella isolates were positive after repeated sub culturing, biochemical and serological tests. Nineteen (63\%) of the 30 isolates were positive for 16 SrRNAs, five (17\%) for sitC while thefliC was negative.

Conclusion: The PCR assay has proven to an efficient method for the identification of virulence genes in Salmonellaserovars. The presence of 16 SrRNAs andsitC genes showed availability of the virulence genes in retailed raw meat samples commonly sold in Nigeria. More studies are required to track virulence factors among Salmonella isolates in Nigeria.
\end{abstract}

Keywords:Genes, Nigeria, PCR, Salmonella, Virulence

\section{Introduction}

Salmonellabelong to the family Enterobacteriaceae, and responsible for most foodborne infections posing a major public health challenge worldwide [1]. Infection with Salmonella can lead to serious and potentially fatal infections including bacteraemia, septic arthritis, meningitis and pneumonia [2]. Faecal-oral transmission of Salmonella occurs most commonly through the consumption of contaminated food causing salmonellosisin humans [3].

Salmonella entericacontains about 2,600 serovars and are classified into six subspecies with high sequence resemblance[4]. The most frequently isolated serovarsfrom foodborne outbreaks are SalmonellaentericserovarsS. typhimuriumandS. enteritidis. Salmonella relies on multiple virulence factors, many of which are clustered within Salmonella pathogenicity islands (SPIs) to cause a disease, and five (1-5) SPIs have been identified so far [5]. The 16SribosomalRNA (16SrRNA) is one of the Salmonellapathogenicity island I virulence genes[6]. The use of $16 \operatorname{Sr} R N A$ gene sequencing within the regulatory workflow may help to reduce the time and labor involved in the identification and differentiation of Salmonellaenterica isolates. Salmonellaentericais subdivided into six subspecies: enterica(I), salamae(II), arizonae(IIIa), diarizonae(IIIb), houtenae(IV), and indica(VI), the more commonly isolated subspecies are; (II, IIIa, IIIb, IV) [7], and Subspecies' I ismost responsible for infections in human and domestic animal infections. The Salmonellaserovars are clinically recognized according to the disease they cause; typhoid or enteric are life threatening infections and non-typhoidalserovars which cause self-limiting gastroenteritis [8,9]

The serovars are known to cause majority of infection in both humans and animals resulting in major economic loss. Salmonella outbreaks have been implicated with improper handling of food by food handlers [10], and different Salmonellae pathogens have various host ranges; some isolates infect animal and plant hosts, while others have specific host. 
In developed countries up to $5 \%$ cases of NTS may be invasive, extra-intestinal disease leading to bacteremia, but in Sub-Saharan Africa the invasive non-yphoidalSalmonella (iNTS) is responsible for high morbidity and mortality in adults and children, with an estimated annual incidence of 175-388 cases per 100000 children and 2000-7500 cases per $100000 \mathrm{HIV-infected} \mathrm{adults} \mathrm{[11].}$

The remarkable feature of fliCalleles is the sequence conservation of distal parts of the gene, thus making the gene of any serotype suitable for easy amplification. Most Salmonella strains possess two structural genes $(f l i C$ and $f l i B)$ coding forflagellins[12].

The sitC (Salmonella iron transporter C) gene is a virulence gene found in Salmonellaenterica strains which is involved in iron transport, its broad action includes invasion of macrophages and iron acquisition. The sitC is found in Salmonella Pathogenicity Island 1(SPI-1)[13,14].

The advent of molecular methods for diagnosis of infectious diseases has improved the sensitivity, specificity and quality of treatment. PCR studies have shown the specificity of some gene primers such as $16 \mathrm{~S}$ ribosomal RNA (16SrRNA) to detect and discriminate between Salmonella and non-Salmonella species[6].The common sources of Salmonella include dairy products, beef, poultry, eggs and vegetables. Detection of the virulence genes is essential to understanding oftheetiologic agent which may provide insight into their relative pathogenicity, treatment and develop prophylactic strategies for salmonellosis. This study is aimed at identifying Salmonella present among retailed raw meat samples in Nigeria using primers; $16 \mathrm{SrRNA}$, sitC and $f l i C$ virulence genes which are specific to Salmonelladetection and diagnosis

\subsection{Salmonella isolates}

\section{Materials and Methods}

A total of thirty samples of raw meat were collectedfromMushin market, Lagos between August and September 2013. Thesamples selected were suspected for possiblecontaminationbySalmonelladuring the retail handling and storageprocessof raw meats. The collectedsampleswere placed aseptic in a polyethylene bags, labeled and refrigerated at $-4^{\circ} \mathrm{Cfor}$ about $24 \mathrm{~h}$ before processing. The use of pre-enrichmentbrothof samples was performed as described earlier [16].We used $25 \mathrm{~g}$ of the meat samples to homogenizein $225 \mathrm{~mL}$ of buffered peptone water broth,incubatedat $37^{\circ} \mathrm{C}$ for $24 \mathrm{~h}$. The culture from pre-enriched broth was thendivided into two aliquots; first aliquot was subjected toconventionalculturalmethod. All the isolates that produced $\mathrm{H}_{2} \mathrm{~S}$ on deoxycholate agar plates were subjected to biochemical tests (IMViC tests; "I- indole test, M-methyl red test, VVoges-Proskauer test, and C-citrate test; Kligler Iron Agar (KIA) test, Motility Indole Urea (MIU) test and Simmons' Citrate test), while the second aliquot was used for DNA extraction by boiling method followed by agarose gel electrophoresis and PCR to confirm the presence of Salmonella.

\subsection{Serological test}

The Serological testing was performed using the Salmonella test kit (Oxoid), with $25 \mathrm{mg}$ samples were homogenized with $225 \mathrm{~mL}$ buffered peptone water medium and incubated for $15-18 \mathrm{~h}$ at $37^{\circ} \mathrm{C} .1 \mathrm{~mL}$ of preenriched broth culturewere transferred to $9 \mathrm{~mL}$ of selenite cysteine enrichment broth culture and incubated at 37 ${ }^{\circ} \mathrm{C}$ for $24 \mathrm{~h}$. One drop of the selenite cysteine enrichment broth culture using a Pasteur pipette were dropped within one circle on the reaction card and mixed with 1 drop of the OxoidSalmonella Latex Reagent to the broth on the card. The suspension was mixed thoroughly using a clean mixing stick or inoculating loop, and then rocked the reaction card gently for 2 or 3 times. The agglutination was examinedwithin a maximum of $2 \mathrm{~min}$.

\subsection{Genomic DNA extraction}

Three colonies of each isolate were picked and suspended in $200 \mu \mathrm{l}$ of distilled water and mixed by vortexing. Genomic DNA was extracted by the boiling method and briefly $1.5 \mathrm{ml}$ of the sample in broth was centrifuged at 10,000rpm for 5 minutes. The supernatant was discarded and the pellets were washed twice with sterile water. After this, $200 \mu 1$ of sterile water was added to the pellets, the pellets were vortexed to homogenize and boiled in a dry bath at $100^{\circ} \mathrm{C}$ for 10 minutes. This was followed by vortexing and centrifugation at 12,000rpm for 5 minutes. The supernantant was transfered into another pre-labelled eppendorf tube by gentle aspiration using a micropipette. The supernatant contains the DNA needed for PCR assay, and was stored at $20^{\circ} \mathrm{C}$. The concentration and purity of the extracted DNA was estimated using a nanodrop spectrophotometer and the integrity of the DNA was assessed by $1 \%$ agarose gel electrophoresis.

2.5 Primers: $16 \operatorname{Sr} R N A$ (F-5' TGT TGT GGT TAA TAA CCG CA 3' and R- 5' CAC AAA TCC ATC TCT GGA 3'), sitC (F-5' CAG TAT ATG CTC AAC GCG ATG TGG GTC TCC 3'and R-5'CGG GGC GAA AAT AAA GGC TGT GAT GAA C 3') and Flagellin(F-5' AAG GAA AAG ATC ATC WAY 3' and R-5' TTA ACC CAG TAA AGA GAG 3').

2.5 Polymerase chain reaction (PCR) procedure using 16SrRNA, sitCand $f l i C$ primersPCR was conducted in a volume of $25 \mu \mathrm{l}$ containing $2 \mu \mathrm{l}$ of genomic DNA from the salmonella isolates, $12.5 \mu \mathrm{lmastermix}, 2 \mu \mathrm{l}$ of each primers specific for $16 \mathrm{SrRNA}$, sitC and fliCgene and $8.5 \mu \mathrm{l}$ of deionized distilled water (DDW). The cycling 
conditions for amplification in a Gene Amp PCR System 9700 thermal cycler (Applied Biosystem, India)was as follows; $16 \mathrm{SrRNA}$ primer-initial denaturation step of $95^{\circ} \mathrm{C}$ for $3 \mathrm{mins}$ followed by 30 cycles consisting of $30 \mathrm{sec}$ at $95^{\circ} \mathrm{C}, 30 \mathrm{~s}$ at $54.1^{\circ} \mathrm{C}$, and a final extension step of $1 \mathrm{~min}$ at $72^{\circ} \mathrm{C}$, sitC $-94^{\circ} \mathrm{C}$ for 3 mins followed by 30 cycles consisting of; a denaturation step of $2 \mathrm{mins}$ at $94^{\circ} \mathrm{C}, 1 \mathrm{mi}$ at $55^{\circ} \mathrm{C}$ and final extension step of $1 \mathrm{~min}$ at $72^{\circ} \mathrm{C}$, fliC primer: $94^{\circ} \mathrm{C}$ for 2 mins followed by 35 cycles each consisting of $30 \mathrm{~s}$ at $94^{\circ} \mathrm{C}, 30 \mathrm{~s}$ at $55^{\circ} \mathrm{C}$ and an extension step of $72^{\circ} \mathrm{C}$ for $1 \mathrm{~min}$. the above PCR cycling conditions were based on the preliminary experiments performed to optimize amplification of salmonella target sequences. Following electrophoresis, the gel was stained withethidium bromide and photographed under transilluminatorultraviolet (UV) light. A 100 bp DNA ladder (MBI Fermentas USA)were used as markers for determining the molecularweight of PCR products ([17]. The amplified products were electrophoresed for the presence of desired bands on $1.5 \%$ agarose gel.

\section{Result3.1 PCR identification of Salmonella using the 16SrRNA primer}

Nineteen (63\%) isolates of the thirty (30) samples showed amplification for the 16SrRNA gene using the primer set $16 \operatorname{Sr} R N A(\mathrm{~F}-5$ ' TGT TGT GGT TAA TAA CCG CA 3' and R- 5' CAC AAA TCC ATC TCT GGA 3'). The molecular weight of the amplicon was $574 \mathrm{bp}$ as shown in plate 1 . The positive control (Salmonella typhimurium) also contained the amplified 574bp DNA fragment. Plate 1 which showed Lanes 1 to 4 is a representative of the amplification result for the $16 \operatorname{SrRNA}$ gene.

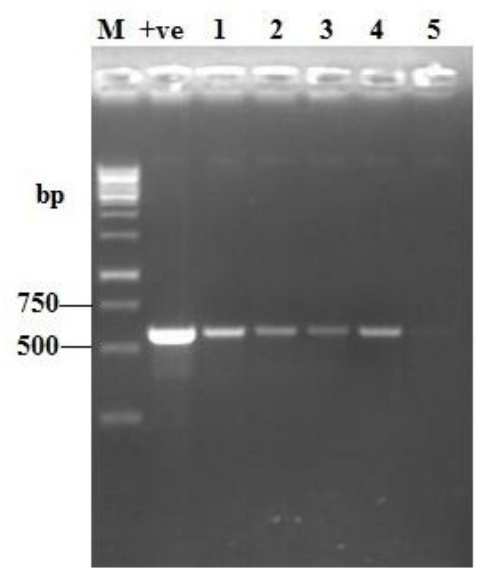

Plate 1: Representative sample of amplified 574-bp DNA fragment of the 16SrRNAgene.Lane $\mathrm{M}=1$ kilobase pair ladder, Lane $+=$ positive control, Lane $5=$ Negative, Lane 1 to 4 positive.

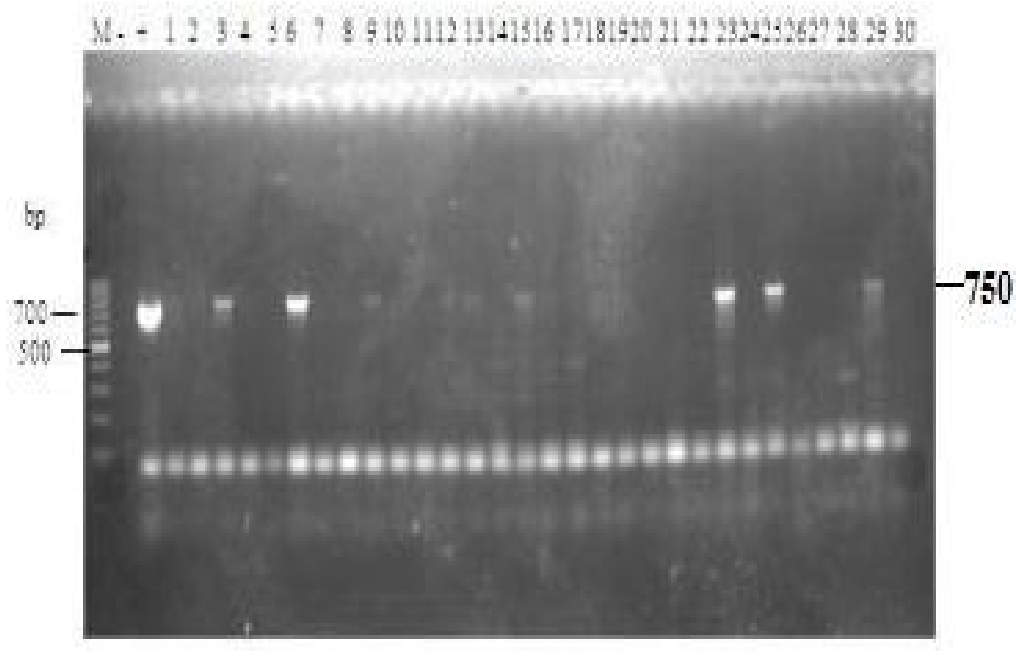

Plate 2: Agarose gel electrophoresis of amplified 750-bp DNA fragment of the sitCgene.Lane M = 100 base pair marker, Lane $-=$ negative control, Lane $+=$ positive control, Lanes 3, 6, 23, 25, $28=$ positive (5). 


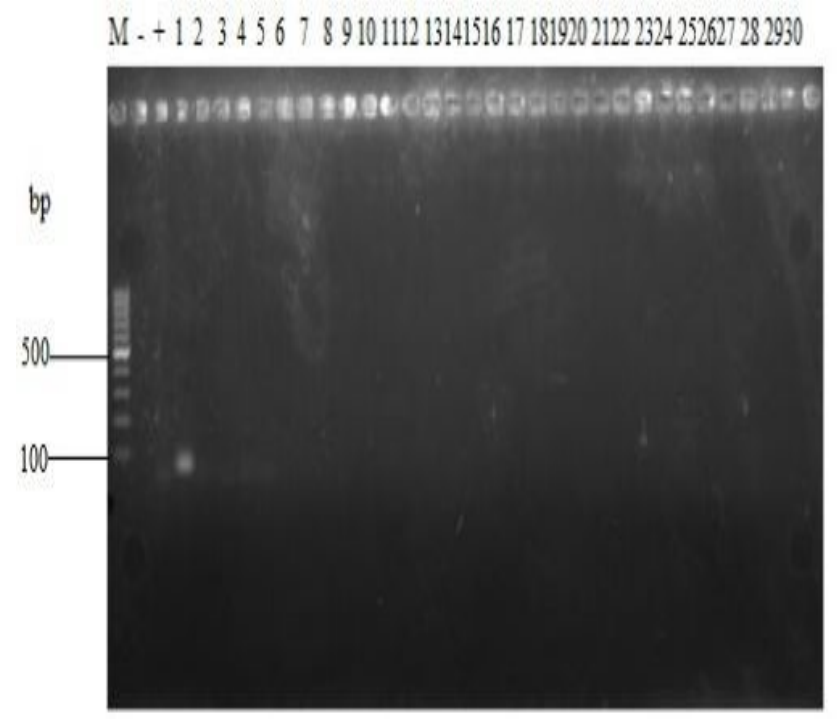

Plate 3: Agarose gel electrophoresis of flagellin gene using flagellinfliCprimer.Lane $\mathrm{M}=100$ base pair marker, Lane $-\mathrm{ve}=$ negative control, Lane $+\mathrm{ve}=$ positive control (which showed no amplification for the gene), Lanes 1 to $30=$ negative.

\section{Discussion}

Strains of Salmonellaare considered as important pathogens and a leading cause of bacterial food-borne illness popularly known as Salmonellosis and is a major public health problems. Genomic variations play an important role in bacterial identification, it is necessary to use molecular techniques known to be sensitive and specific to identify suspected Salmonellaserovars[18].

In this study, PCR method based on the 16SrRNAsitC and fliCtargetingSalmonellavirulencegenes were

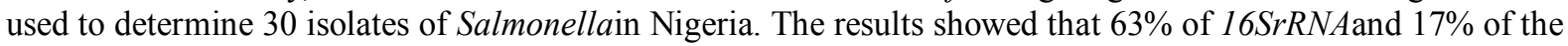
isolates matched with the Salmonella typhimurium. The PCR analyses of the virulence genesdemonstrated suitable targetgene for discriminating among Salmonellaserotypes. Studies have also shown that this method is rapid and reproducible in identification ofisolates[19]. Theseresults showed that these methods can potentially beapplied for identification of Salmonella typhimurium

Various primers sets targeting Salmonella16SrRNA, sitC and fliC genes have been designed for research purposes [20, 21]. 16SrRNA primer can be used for the detection of Salmonella in food samples (Lin and Tsen. 1996. The 16SrRNA primer amplified DNA from most of the Salmonella strains successfully. Recent study on the molecular epidemiology and in vitro antimicrobial susceptibility of Salmonella isolated from poultry in Kashmir valley, India showed that all the isolates of Salmonellawere tested by genus-specific polymerase chain reaction (PCR), using the 16S ribosomal RNA (rRNA) primers [22,23].

Out of a total of 30 suspected Salmonella isolate samples used for this study, the $16 \mathrm{SrRNA}$ primer set amplified 19 samples as positives with an amplicon size of $574 \mathrm{bp}$, and this corroborated earlier work done [13] that non-typhoidalSalmonella isolates from human, animal and food products in The Gambia and Senegal for the presence of twelve virulence genes including sitC. The sitCgene was found in at least $70 \%$ of the isolates tested [13], and this showed a significant association between the sitC virulence gene and resistance to commonly used antibiotics in West African region. Our worked on the other hand showed $17 \%$ of sitCgenewithamplicon size of $750 \mathrm{bp}$. This also corroborated earlier reported use of sitC gene in differentiation and detection of Salmonella typhiin range of animal and human origin, and this gene was found to be associated with severity of salmonellosis in humans [24, 20].

We did not observe fliCgeneamplificationin any of the samples suggesting that the identified Salmonella species may lackfliC gene or may be due to inadequate primer amplification.

Adequate sanitary measures have led to a decrease in cases of typhoidalSalmonellae in developed countries and most cases are associated with travellers returning from endemic areas in developing countries. In sub-Sahara Africa such as the Gambia and Senegal, non-typhoidalSalmonella(NTS) becoming a major cause of invasive disease in infants, young children, and HIV-infected adults and are associated with substantial mortality [13].

In Nigeria, morbidity associated with illnesses due toSalmonellacontinues to be on the increase and, in some cases, resulting in death [25]. Proper characterization of Salmonellaisolates is essential for investigations of Salmonella outbreaks as non-typhoidalSalmonellastrains have reached epidemic proportions in manycountries despite improvements in sanitation and hygiene [26]. In view of limited adherence to high standards of hygiene, 
the probability of bacterial contamination of food at various stages of processing is always very high [27].Salmonella species used for research purposes are usually isolated from contaminated food and clinical samples which are mostly due to faecal-oralroutes[4].

This result showed a recognisable distribution of 16SrRNA and sitCvirulence genes in Salmonella species gotten from meat samples sourced from Nigeria. The most prevalent gene was $16 \operatorname{SrRNA}(63 \%)$, and this suggests that 16SrRNA can be used for the identification and confirmation ofSalmonellainfood samples using the PCR method.

\section{Conclusion}

Infection caused by Salmonella species remains an important public health problem especially in developing countries. This study showed that virulence genes are present in non typhoidalSalmonella isolates found in Nigeria. The 16SrRNA is a suitable molecular tool to diagnose Salmonellainanimal products. Identification of Salmonellaserovarsthroughscreening of virulence genes by PCR methods can have benefits in public health specifically for rapid diagnosis, development of treatment and epidemiological investigations. More studies are required to track availability and emergence of virulence factors in Salmonella isolates in Nigeria.

\section{Acknowledgement}

The Authors thanked the management of Nigerian institute of Medical Research, staff and Director of Molecular Biology and Biotechnology laboratory for their unflinching technical support. Our sincere appreciation also goes to Mrs. C.E Adamuof Lagos University Teaching Hospital who supported the work morally and financially.

Conflict of InterestAuthors declare that they no conflict of interest.

\section{References}

[1]. E. Galanis, M.A.Danilo, F.L. Wong, M.E. Patrick, N.Binsztein, A.Cieslik, T.Chalermchaikit,A.Aidara-Kane, A.Ellis, F.J.Angulo, H.C. Wegener (2006). Web-basedsurveillance and global Salmonella distribution, 2000-2002. Emerging. Infectious Disease, 12(3),2006, 381-388

[2]. N.D. Cohen, L.H. Neibergs, D.E. McGruder, W.H. Whitford, W.R. Behle, M.P. Ray, and M.B. Hargis (1993). Genus-specific detection of Salmonellae using the Polymerase Chain Reaction (PCR). Journal of Veterinary Diagnostic Investigation, 5,1993, 368371.

[3]. C. Magistral, M.A. Dionisi, P. De Curtis , L. Cucco, O.Vischi , S. Scuota, A. Zicavo, andG. Pezzotti. Contamination of Salmonella spp in a pig finishing herd, from the arrival of the animals to the slaughterhouse. Research in Veterinary Science, 85 , 2008, 204-207.

[4]. A. Bennasar, G. de Luna, B. Cabrer, andJ.Lalucat. Rapid identification of Salmonellatyphimurium, S.Enterica and S. Virchov isolates by polymerase chain reaction based fingerprinting methods. International Microbiology, 3, 2000, 31-38

[5]. L. Settanni, and A. Corsetti The use of multiplex PCR to detect and differentiate food and beverage-associated microorganisms: a review Journal of Microbiological Methods, 69(1), 2007, 1-22.

[6]. C. J. Ziemer, and R.S. Steadham. Evaluation of the specificity of Salmonella PCR primers using various intestinal bacterial species. Letters in Applied Microbiology 37, 2003, 463-469.

[7]. Centers for Disease Prevention and Control. Public Health Laboratory Information System surveillance data: annual Salmonella summaries 1995-2006. http://www.cdc.gov/ncidod/

[8]. M. C. Parry, T.T Hien, G. Dougan, J.N White, and J.J. Farrar. Typhoid fever. New England Journal of Medicine, 347, 2002: 17701782 .

[9]. S.Zhang, A.R. Kingsley, L.R. Santos, H. Andrews-Polymenis, M. Raffatellu, J. Figueiredo, J. Nunes, M.R Tsolis, G.L Adams, and J. A Bäumler. Molecular pathogenesis of Salmonella enterica serotype typhimurium-induced diarrhoea. Infection and Immunity, 71(1), 2003:1-12.

[10]. R. Gorman, S. Bloomfield, and C.C. Adley(2002). A study of cross-contamination of food-borne pathogens in the domestic kitchen in the Republic offreland. International Journal of Food Microbiology, 76, 2002, 143-150.

[11]. A. N. Feasey, G. Dougan, A.K. Kingsley, S.R. Heyderman, and A.M. Gordon. Invasive non-typhoidalSalmonella disease: an emerging and neglected tropical disease in Africa. Lancet, 379(9835), 2012, 2489-2499.

[12]. K.C. Mortimer, F.S. Gharbia, M.J. Logan,M. T. Peters, and C. Arnold. Flagellin gene sequence evolution in Salmonella Infection, Genetics and Evolution, 7(4), 2007, 411-415.

[13]. M.M Dione, U. Ikumapayi ,D. Saha, I.N. Mohammed, A.R.Adegbola, S. Geerts , M. Ieven, and M. Antonio. Antimicrobial resistance and virulence genes of non-typhoidalSalmonella isolates in the Gambia and Senegal. The Journal of InfectioninDeveloping Countries. 5(11),2011, 765-775.

[14]. D, Zhou, D. WHardt, andE. J. Galan.Salmonellatyphimurium encodes a putative iron transport system within the centisome 63 pathogenicity island. Infection and Immunity, 67(4), 1999, 1974-1981

[15]. K. Rahn, A. S. De Grandis, C. R. Clarke, A.S. McEwen, E.J. Galan, C. Ginocchio, R. Curtiss, and L.C. Gyles. Amplification of an invA gene sequence of Salmonella typhimurium by polymerase chain reaction as a specific method of detection of Salmonella. Molecular and Cellular Probes 6, 1992, 271-279

[16]. D.D. Medici, L. Croc,E.Delibato, D.S. Pasquale, E. Filetici, and L. Toti. Evaluation of DNA extraction methods for use in combination with SYBR Green I real-time PCR to detect Salmonella enterica Serotype Enteritidis in poultry, Applied EnvironmentalMicrobiology, 69, 2003, 3456-3461.

[17]. S. Nair, T. Kwai Lin, T. Pang, and M. Altwegg. Characterization of salmonella serovars by PCR-single-strand conformation polymorphism analysis. Journa of Clinical Microbiology, 40, 2002, 2346-2351 
[18]. J. Akbarmehr, T. ZahraeiSalehi, and h.gNikbakhtBrujeni . Identification of Salmonella isolated from poultry by MPCR technique and evaluation of their hspgroEL gene diversity based on the PCR-RFLP analysis, African Journal of Microbiology Research, 4, 2010, 1594-1598.

[19]. A.M. Gallegos-Robles, A. Morales-Loredo, G. Alvarez-Ojeda, A. Vega-P, Y. Chew-M, S. Velarde, and A. Fratamico. Identification of Salmonella Serotypes isolated from cantaloupe and chile pepper production systems in Mexico by PCR-Restriction Fragment Length Polymorphism, Journal of Food Protection. 71, 2008, 2217-2222

[20]. M, Hatta, R.A. Sultan, R. Pastoor, and L.H. Smits. New Flagellin gene for Salmonella entericaserovarTyphi from the East Indonesian Archipelago. The American Journal of Tropical Medicine and Hygiene, 84(3), 2011, 429-434.

[21]. D.R. Hellberg, J.C. Haney, Y. Shen, M.C. Cheng, M.D. Williams-Hill, and B.M Martin. Development of a custom 16SrRNA gene library for the identification and molecular subtyping of Salmonella enterica,Journal of Microbiology Methods, 91(3), 2012,448458

[22]. C. Lin andH. Tsen. Use of two 16S DNA targeted oligonucleotides as PCR primers for the specific detection of Salmonella in foods, Journal of Applied Bacteriology, 80, 1996: 659-666

[23]. I. Mir, S. Wani, I. Hussain, D.S. Qureshi, A.M. Bhat, andY. Nishikawa. Molecular epidemiology and in vitro antimicrobial susceptibility of Salmonella isolated from poultry in Kashmir. Revue Scientifque et Technique de l'Office International des Epizooties, 29(3), 2010, 677-686.

[24]. G. Kilger, and A.P. Grimont.Differentiation of Salmonella phase 1 flagellar antigen types by restriction of the amplified fliC gene, Journal of Clinical Microbiology, 31(5), 1993,1108-1110.

[25]. O.K. Akinyemi, O.A. Coker, K. D. Olukoya, O.A. Oyefolu, P.E. Amoroghoye, and O.E. Omonigbehin. Prevalence of multi-drug resistant Salmonella typhiamong clinically diagnosed typhoid fever patients in Lagos, Nigeria, ZurichNaturforsch, 55, 2000,489493.

[26]. J.E. Threlfall, andA.J. Frost. The identification, typing, and fingerprinting of Salmonella; laboratory aspects and epidemiological applications, Journal of AppliedBacteriology, 68, 1990, 5-16.

[27]. I. Ben Salem, M. Aouni, and R. Mzoughi. Specific detection of Salmonella spp in food by multiplex Polymerase Chain Reaction, Advance Studies in Biology, 2(2), 2010,73-88 